J. Clin. Chem. Clin. Biochem.

Vol. 21, 1983, pp. 799-804

\title{
Enzymuria of the Rat: The Preparation of Urine for Enzyme Analysis
}

\author{
By G. Berscheid, H. Grötsch, M. Hropot, E. Klaus
}

Hoechst AG Pharmaforschung Biochemie, Frankfurt/M, GFR, and

\section{H. Mattenheimer}

Rush-Presbyterian-St. Luke's Medical Center, Rush Medical College, Clinical Biochemistry Laboratory, Department of Biochemistry, Chicago, Illinois 60612, U.S.A.

(Received June 6, 1983)

Summary: The effects of sample preparations by dialysis and gel filtration on the catalytic concentrations of alanine aminopeptidase, $\mathrm{N}$-acetyl- $\beta-D$-glucosaminidase, and $\beta$-glucuronidase are described. Individual urines were collected during 24 hours on 3 consecutive days from 10 male rats. Gel filtration (Sephadex G25) was more effective than dialysis against water in the removal of inhibitors of $\mathrm{N}$-acetyl $-\beta-D$-glucosaminidase and $\beta$ glucuronidase. For alanine aminopeptidase, slightly higher results were obtained by dialysis. Inhibitor contents varied from day to day. Activity decreases of $\beta$-glucuronidase and $\mathrm{N}$-acetyl- $\beta$ - $D$-glucosaminidase were found in some of the urine samples and interpreted as removal of activators. Gel filtration is recommended for the preparation of rat urine for the measurement of these three enzymes. The slightly inferior effect of gel filtration on alanine aminopeptidase should be disregarded for the sake of practicality.

\section{Enzyme im Harn der Ratte: Probenvorbereitung für Enzymanalysen im Harn}

Zusammenfassung: Der Effekt von Dialyse und Gelfiltration zur Probenvorbereitung für die Bestimmung der katalytischen Konzentration von Alaninaminopeptidase, $\mathrm{N}$-Acetyl- $\beta-D$-glucosaminidase und $\beta$-Glucuronidase wird beschrieben. Individuelle Urine wurden über 24 Stunden an drei aufeinanderfolgenden Tagen von 10 männlichen Ratten gesammelt. Zur Entfernung von Inhibitoren der $\mathrm{N}$-Acetyl- $\beta$ - $D$-glucosaminidase und $\beta$-Glucurónidase war die Gelfiltration wirksamer als Dialyse gegen Wasser. Gering höhere Aktivität mittels Dialyse wurde für Alaninaminopeptidase gefunden. Die Inhibitorkonzentrationen schwankten von Tag zu Tag. In einigen Proben wurden Aktivitätsverluste von $\mathrm{N}$-Acetyl- $\beta$ - $D$-glucosaminidase und $\beta$-Glucuronidase beobachtet und als Entfernưng von Aktivatoren gedeutet. Es wird empfohlen, zur Messung dieser drei Enzyme Rattenurin mittels Gelfiltration vorzubereiten und die gering schlechtere Wirkung auf Alaninaminopeptidasē zugunsten der Praktikạbilịtätt zu vernachlässigen.

\section{Introduction}

It has been recognized for some time that certain drugs cause hyperenzymuria $(1,2,3)$. Enzyme measurements in urine are therefore one of the means suggested for assessing possible nephrotoxic effects of drugs. However, agreement has yet to be reached on the standardization of urine collection periods, sample preservation during collection, urine preparation for enzyme analysis, and enzyme assays per se.

Urine contains enzyme inhibitors and perhaps activators which must be removed before enzyme analy- 
sis. In this paper, the effects are described of sample preparation by dialysis and gel filtration on the activities of alanine aminopeptidase (EC 3.4.11.2), Nacetyl- $\beta-D$-glucosaminidase (EC 3.2.1.30) and $\beta$ glucuronidase (EC 3.2.1.31).

\section{Materials and Methods}

\section{Urine collection}

Twenty four hour urine was collected on 3 consecutive days from 10 male Wistar rats, weighing around $200 \mathrm{~g}$. The animals were kept in individual cages. Sodium azide was added to the urine collection vessels as preservative.

\section{Centrifugation}

Urine samples were centrifuged for 10 minutes at $1000 \mathrm{~g}$ in a refrigerated centrifuge (temperature ca. $10^{\circ} \mathrm{C}$ ) and separated from the sediment. The supernatant is designated as crude urine.

\section{Dialysis}

Two $\mathrm{ml}$ of crude urine were dialysed in Visking dialysis tubing (Serva, Heidelberg, type 8/32, No. 44104) at room temperature for 90 minutes against flowing tap water. The filled tubes were weighed before and after dialysis for volume correction.

\section{Gel filtration}

Sephadex-G25M-PD10 columns (Pharmacia, Uppsala) were prepared as suggested by the manufacturer. The columns were equilibrated with $4 \mathrm{ml} 150 \mathrm{mmol} / 1 \mathrm{NaCl}$ solution, charged with $2.5 \mathrm{ml}$ of crude urine, and eluted with $4 \mathrm{ml} 150 \mathrm{mmol} / \mathrm{I} \mathrm{NaCl}$ solution. The eluate contained the total enzyme catalytic activity. The columns were regenerated by washing with $10-15 \mathrm{ml}$ bidistilled or deionized water, and were again ready for use. Sodium azide solution $(15 \mathrm{mmol} / \mathrm{h})$ was added for storage.

Reagents for enzyme assays

(A) Phosphate buffer, $100 \mathrm{mmol} / \mathrm{p}, \mathrm{pH} 7.60$

(B) Citrate buffer, $100 \mathrm{mmol} / \mathrm{pH} 4.15$

(C) Acetate buffer, $100 \mathrm{mmol} / \mathrm{l}, \mathrm{pH} 4.60$

(D) Alanine aminopeptidase substrate: alanine nitroanilide 16.6 $\mathrm{mmol} / \mathrm{h}$ in bidistilled or deionized water. The refrigerated solution is stable for about 1 week.

(E) N-Acetyl- $\beta$ - $D$-glucosaminidase substrate: 4-nitrophenyl- $\mathrm{N}$ acetyl- $\beta$ - $D$-glucosaminide, $10 \mathrm{mmol} / \mathrm{l}$, in citrate buffer $(\mathrm{B})$. The refrigerated solution is stable for about 1 week.

(F) $\beta$-Glucuronidase substrate: 4-nitrophenyl-glucuronide 40 $\mathrm{mmol} / \mathrm{l}$ in bidistilled or deionized water. The refrigerated solution is stable for about 1 week.

(G) Glycine buffer, $400 \mathrm{mmol} / \mathrm{l}, \mathrm{pH} 10.5$.

\section{Enzyme assays}

Microliter methods were used for the enzyme determinations.

\section{Alanine aminopeptidase}

Alanine aminopeptidase was determined continuously at $405 \mathrm{~nm}$ and $25^{\circ} \mathrm{C}(4)$ in the Gemsaec Fast Analyzer. Concentrations in the incubation mixture were: phosphate buffer (A) $70 \mathrm{mmol} / \mathrm{l}$, substrate (D) $1.66 \mathrm{mmol} / \mathrm{l}$. sample volume fraction 0.2 .

\section{$\beta$-Glucuronidase}

$\beta$-Glucuronidase was determined by a two point method (5) at $37^{\circ} \mathrm{C}$ and $30 \mathrm{~min}$ incubation. The concentrations in the incubation mixture were: acetate buffer (C) $40 \mathrm{mmol} / \mathrm{h}$, substrate (F), 8 $\mathrm{mmol} /$, sample volume fraction 0.2 . The reaction was stopped by adding glycine buffer $(G)$ (four times the volume of the incubation mixture). A sample blank with water instead of substrate, and a reagent blank with water instead of sample, were treated in the same manner. Spectrophotometric readings were taken at 405 $\mathrm{nm}$.

\section{$N$-Acetyl $-\beta=D$-glucosaminidase}

$\mathrm{N}$-Acetyl- $\beta$ - $D$-glucosaminidase was determined by a two point method (6) at $37^{\circ} \mathrm{C}$ and $30 \mathrm{~min}$ incubation. Concentrations in the incubation mixture were: citrate buffer $(B, E) 80 \mathrm{mmol} / \mathrm{l}$, substrate (E) $9 \mathrm{mmol} /$, sample volume fraction 0.2 . The reaction was stopped by adding glycine buffer $(G)$ (twice the volume of the incubation mixture). A sample blank with buffer (B) instead of buffer/substrate (E), and a reagent blank with water instead of sample, were treated in the same manner. Spectrôphotometric readings were taken at $405 \mathrm{~nm}$.

\section{Results}

\section{Effect of dialysis and gel filtration}

The data obtained on urine collected during three consecutive 24 h collection periods are shown in table 1 . The mean catalytic activity differences, expressed as $\% \bar{\Delta}$, between dialysed and crude urine, gel filtered and crude urine, and gel filtered and dialysed urine varied somewhat from day to day as an expression of varying inhibitor concentrations. Dialysis was slightly more effective than gel filtration in the removal of inhibitors of alanine aminopeptidase, while for $\mathrm{N}$-acetyl- $\beta-D$-glucosaminidase and $\beta$-glucuronidase gel filtration led to higher activity. $\beta$-Glucuronidase actually lost activity during dialysis against water. When urine was dialysed against 150 $\mathrm{mmol} / \mathrm{l} \mathrm{NaCl}$ in a few parallel experiments, the activity of $\beta$-glucuronidase increased (not shown in table 1).

The combined results of the three collection periods are shown in figs. 1-3 together with the regression line parameters.

\section{Imprecision}

Within-run imprecision of enżyme assays, determined on repeated analyses of gel filtered urine, was in acceptable ranges (tab. 2). Day to day imprecision, assessed with commercial quality control preparations, was satisfactory (tab. 3). Because of inadequate volumes of rat urine, imprecision of gel filtration within and between columns covild not be checked. With human urine, coefficients of variation between 3 and $6 \%$ were obtained, except for low $\beta$ glucuronidase catalytic activity concentration $(0.8$ U/1 with a CV of $15 \%$ (7)). if 
Tab. 1. Mean catalytic activity concentration differences in percent $(\% \bar{\Delta})$ of enzymes measured in crude urine and samples prepared by dialysis and gel filtration.

\begin{tabular}{|c|c|c|c|c|c|c|c|c|c|}
\hline & \multicolumn{3}{|c|}{ Dialysis/crude } & \multicolumn{3}{|c|}{ Gel filtered/crude } & \multicolumn{3}{|c|}{ Gel filtered/dialysis } \\
\hline & Day 1 & Day 2 & Day 3 & Day 1 & Day 2 & Day 3 & Day 1 & Day 2 & Day 3 \\
\hline \multicolumn{10}{|c|}{ Alanine aminopeptidase } \\
\hline $\begin{array}{l}\% \bar{\Delta} \\
2 p \\
r\end{array}$ & $\begin{array}{c}133 \\
<0.001 \\
0.9726\end{array}$ & $\begin{array}{c}140 \\
<0.001 \\
0.9358\end{array}$ & $\begin{array}{c}119 \\
<0.001 \\
0.9537\end{array}$ & $\begin{array}{c}126 \\
<0.001 \\
0.9663\end{array}$ & $\begin{array}{c}130 \\
<0.001 \\
0.9029\end{array}$ & $\begin{array}{c}115 \\
<0.001 \\
0.9345\end{array}$ & $\begin{array}{c}95 \\
<0.005 \\
0.9944\end{array}$ & $\begin{array}{c}93 \\
<0.001 \\
0.9898\end{array}$ & $\begin{array}{l}97 \\
\text { NS } \\
0.9753\end{array}$ \\
\hline \multicolumn{10}{|c|}{ N-Acetyl- $\beta$ - $D$-glucosaminidase } \\
\hline $\begin{array}{l}\% \bar{\Delta} \\
2 p \\
r\end{array}$ & $\begin{array}{c}113 \\
<0.001 \\
0.9760\end{array}$ & $\begin{array}{c}113 \\
<0.001 \\
0.9874\end{array}$ & $\begin{array}{l}103 \\
\text { NS } \\
0.9353\end{array}$ & $\begin{array}{c}130 \\
<0.001 \\
0.94 .59\end{array}$ & $\begin{array}{c}126 \\
<0.001 \\
0.9660\end{array}$ & $\begin{array}{c}124 \\
<0.001 \\
0.9663\end{array}$ & $\begin{array}{c}116 \\
<0.001 \\
0.9680\end{array}$ & $\begin{array}{c}111 \\
<0.001 \\
9.9794\end{array}$ & $\begin{array}{c}121 \\
<0.001 \\
0.8862\end{array}$ \\
\hline \multicolumn{10}{|c|}{$\beta$-Glucuronidase } \\
\hline $\begin{array}{l}\% \bar{\Delta} \\
2 p \\
r\end{array}$ & $\begin{array}{c}86 \\
<0.001 \\
0.9790\end{array}$ & $\begin{array}{c}76 \\
<0.001 \\
0.9642\end{array}$ & $\begin{array}{c}79 \\
<0.01 \\
0.9004\end{array}$ & $\begin{array}{c}134 \\
<0.005 \\
0.9829\end{array}$ & $\begin{array}{l}109 \\
\text { NS } \\
0.9570\end{array}$ & $\begin{array}{c}123 \\
<0.01 \\
0.9739\end{array}$ & $\begin{array}{c}156 \\
<0.001 \\
0.9854\end{array}$ & $\begin{array}{c}144 \\
<0.01 \\
0.9573\end{array}$ & $\begin{array}{c}156 \\
<0.005 \\
0.8996\end{array}$ \\
\hline
\end{tabular}

Tab. 2. Within run imprecision of enzyme analyses (U/l) in gel filtered urine.

\begin{tabular}{llll}
\hline & $\begin{array}{l}\text { Alanine } \\
\text { amino- } \\
\text { peptidase }\end{array}$ & $\begin{array}{l}\text { N-Acetyl- } \\
\beta-D \text {-glucos- } \\
\text { aminidase }\end{array}$ & $\begin{array}{l}\beta- \\
\text { Glucuronid- } \\
\text { ase }\end{array}$ \\
\hline$\overline{\mathrm{x}}$ & 6.56 & 4.90 & 18.0 \\
$\mathrm{~s}$ & 0.08 & 0.15 & 0.32 \\
$\mathrm{CV}(\%)$ & 1.25 & 3.06 & 1.78 \\
$\mathrm{~N}$ & 15 & 10 & 10 \\
$\overline{\mathbf{x}}$ & 9.00 & 22.8 & 31.9 \\
$\mathrm{~s}$ & 0.18 & 0.42 & 0.62 \\
$\mathrm{CV}(\%)$ & 2.0 & 1.84 & 1.94 \\
$\mathrm{~N}$ & 15 & 10 & 10 \\
$\overline{\mathbf{x}}$ & 19.9 & 35.5 & 66.7 \\
$\mathrm{~s}$ & 0.33 & 0.53 & 1.20 \\
$\mathrm{CV}(\%)$ & 1.66 & 1.49 & 1.80 \\
$\mathrm{~N}$ & 15 & 10 & 10 \\
\hline
\end{tabular}

Tab. 3. Day to day imprecision of enzyme analysis (U/l). Commercial quality control preparations were analysed on 10 consecutive working days.

\begin{tabular}{|c|c|c|c|c|}
\hline & & $\begin{array}{l}\text { Alanine } \\
\text { amino- } \\
\text { peptidase }\end{array}$ & $\begin{array}{l}\mathrm{N}=\text { Acetyl- } \\
\beta-D \text {-glu- } \\
\text { cosamini- } \\
\text { dase }\end{array}$ & $\begin{array}{l}\beta \text {-Gluç- } \\
\text { uronidase }\end{array}$ \\
\hline $\begin{array}{l}\text { Normo- } \\
\text { sic }\end{array}$ & $\begin{array}{l}\bar{x} \\
\text { s } \\
\text { CV }(\%)\end{array}$ & $\begin{array}{c}17.0 \\
0.39 \\
2.29\end{array}$ & $\begin{array}{r}17.11 \\
0.85 \\
4.97\end{array}$ & \\
\hline $\begin{array}{l}\text { Kon- } \\
\text { trollo- } \\
\text { gen-LP }\end{array}$ & $\begin{array}{l}\overline{\mathbf{x}} \\
\mathbf{s} \\
\mathrm{CV}(\%)\end{array}$ & $\begin{array}{r}22.35 \\
0.41 \\
1.83\end{array}$ & $\begin{array}{r}24.54 \\
1.04 \\
4.24\end{array}$ & $\begin{array}{l}5.48 \\
0.33 \\
6.02\end{array}$ \\
\hline
\end{tabular}

\section{Discussion}

Urine contains inhibitors for a variety of enzymes (8), but the chemical nature of only a few has been identified (see table in l.c. (9)). While inhibitors for $\mathrm{N}$-acetyl- $\beta-D$-glucosaminidase and alanine aminopeptidase remain unidentified, 1.4-saccharolactone was found to inhibit $\beta$-glucuronidase (10). Among drugs and their metabolites which are excreted in urine, one has also to expect inhibitory substances (11). Preparation of urine samples for removal of inhibitors was therefore generally recommended $(7,8$, 9, 12). Dialysis and gel filtration are currently applied for inhibitor removal. For the latter Sephadex G50 fine was first introduced (13), but Sephadex G25 medium, available in ready-to-use columns with $9 \mathrm{ml}$ bed volume (Pharmacia, PD10), is equally effective (7).

The data presented demonstrate that gel filtration is more effective than dialysis against water in the removal of inhibitors for $\mathrm{N}$-acetyl- $\beta$ - $D$-glucosaminidase and $\beta$-glucuronidase (tab. 1 and figs. 2 and 3). The slightly higher results for alanine aminopeptidase in dialysed urine (fig. 1) are in contrast to alanine aminopeptidase in human urine in which higher activities were obtained by gel filtration (to be published). Day to day variations of inhibition are commonly observed in animal and human urine (e.g. l.c. (14)). This is another reason why urine should be prepared for enzyme analysis. In some instances, inhibition may be overcome by diluting urine. Several investigators used sensitive fluorimetric methods (e.g. for $\mathrm{N}$-acetyl- $\beta$ - $D$-glucosaminidase) with very small sample fractions $(15,16)$ thereby eliminating 


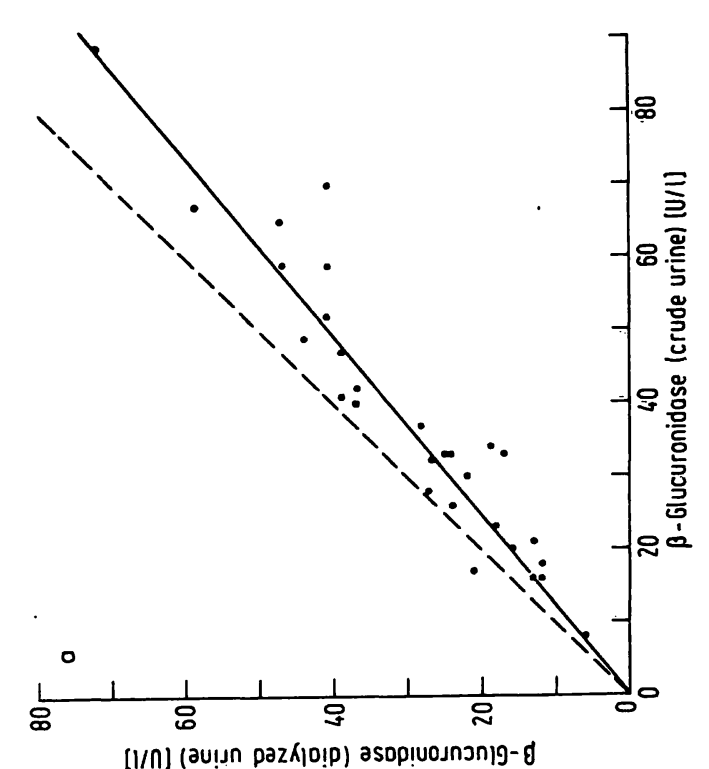

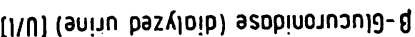
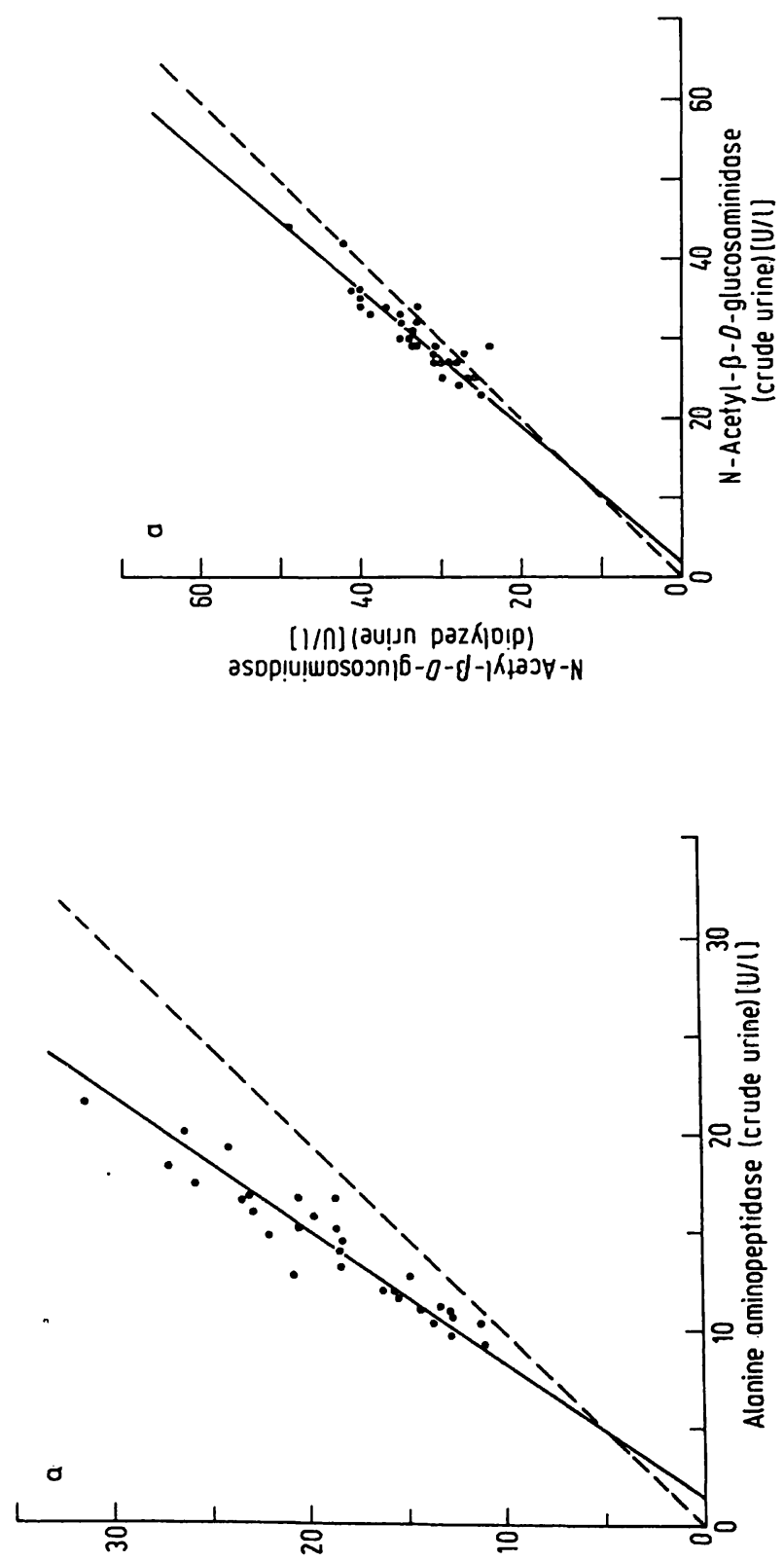

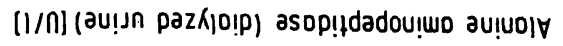
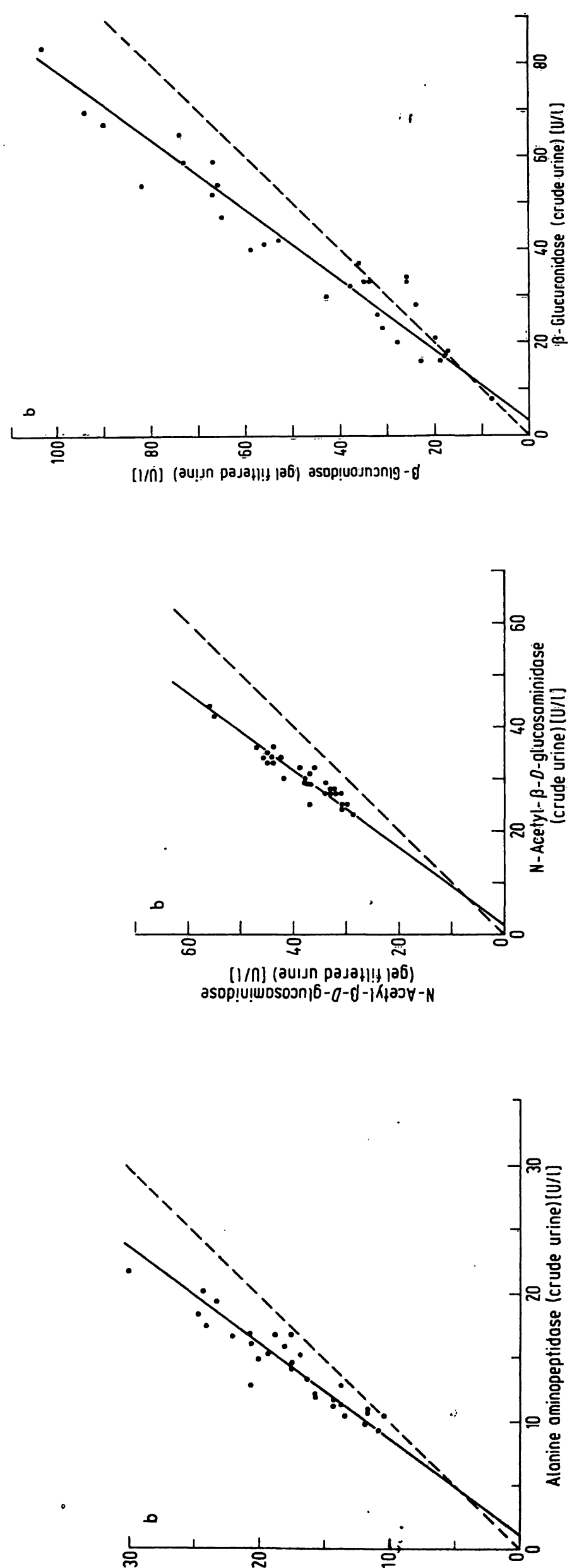

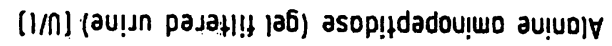



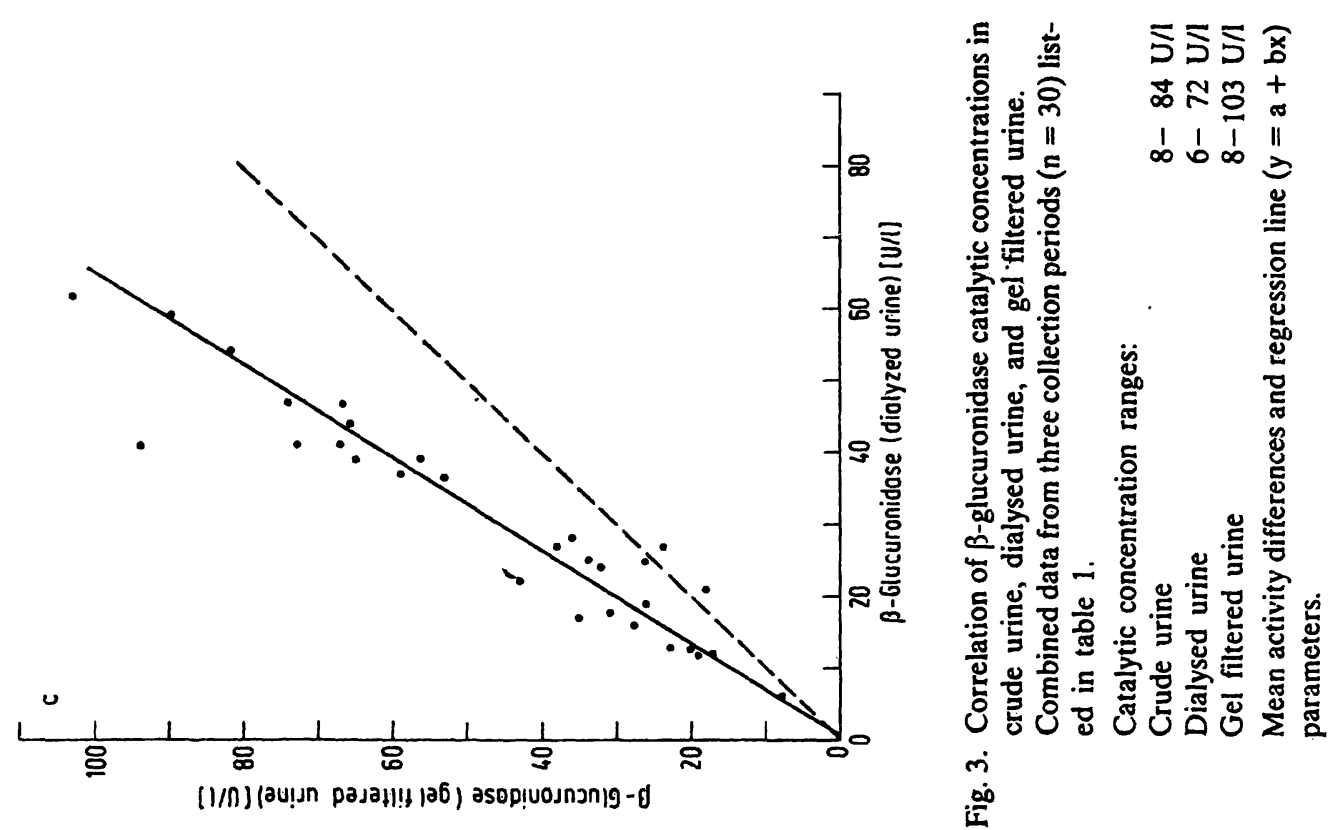

\begin{tabular}{|c|c|}
\hline$\stackrel{\sim}{N}$ & 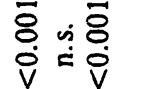 \\
\hline 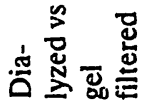 & 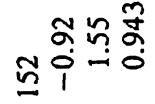 \\
\hline$\stackrel{a}{\sim}$ & 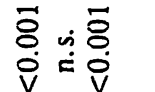 \\
\hline 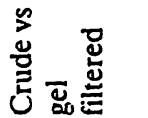 & 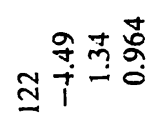 \\
\hline$\stackrel{\vec{N}}{2}$ & 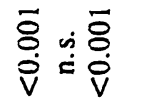 \\
\hline 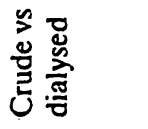 & ஓ \\
\hline$\stackrel{n}{\infty}$ & \\
\hline
\end{tabular}
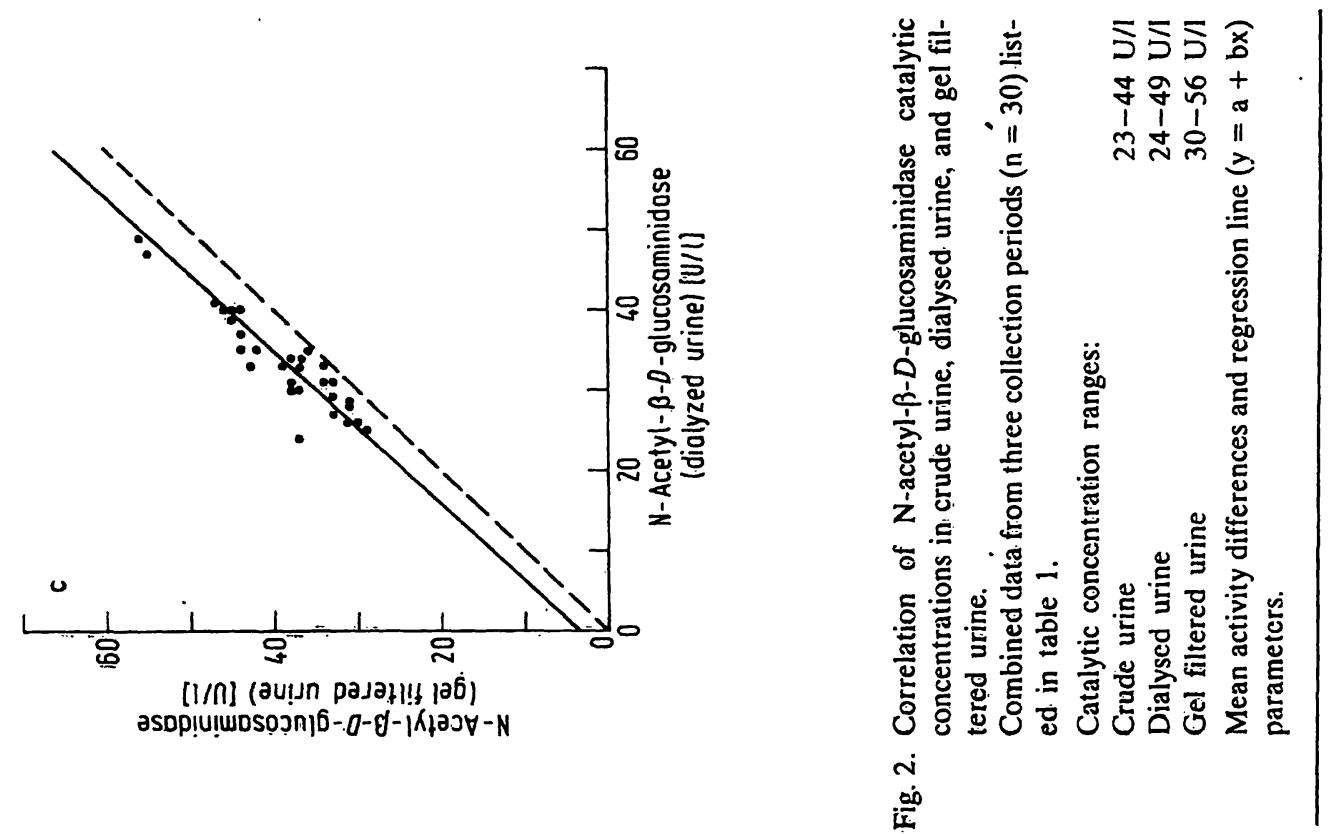

\begin{tabular}{|c|c|}
\hline$\stackrel{\sim}{\sim}$ & 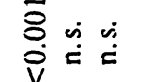 \\
\hline 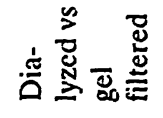 & 윰 \\
\hline$\stackrel{a}{\sim}$ & $\begin{array}{l}\bar{\Xi} \\
\vdots \dot{0} \\
\dot{0}\end{array}$ \\
\hline 总 & 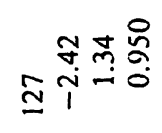 \\
\hline$\stackrel{\sim}{\sim}$ & 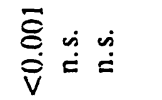 \\
\hline 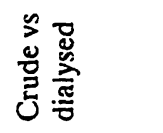 & 옹 \\
\hline$\vec{x}$ & ه \\
\hline
\end{tabular}
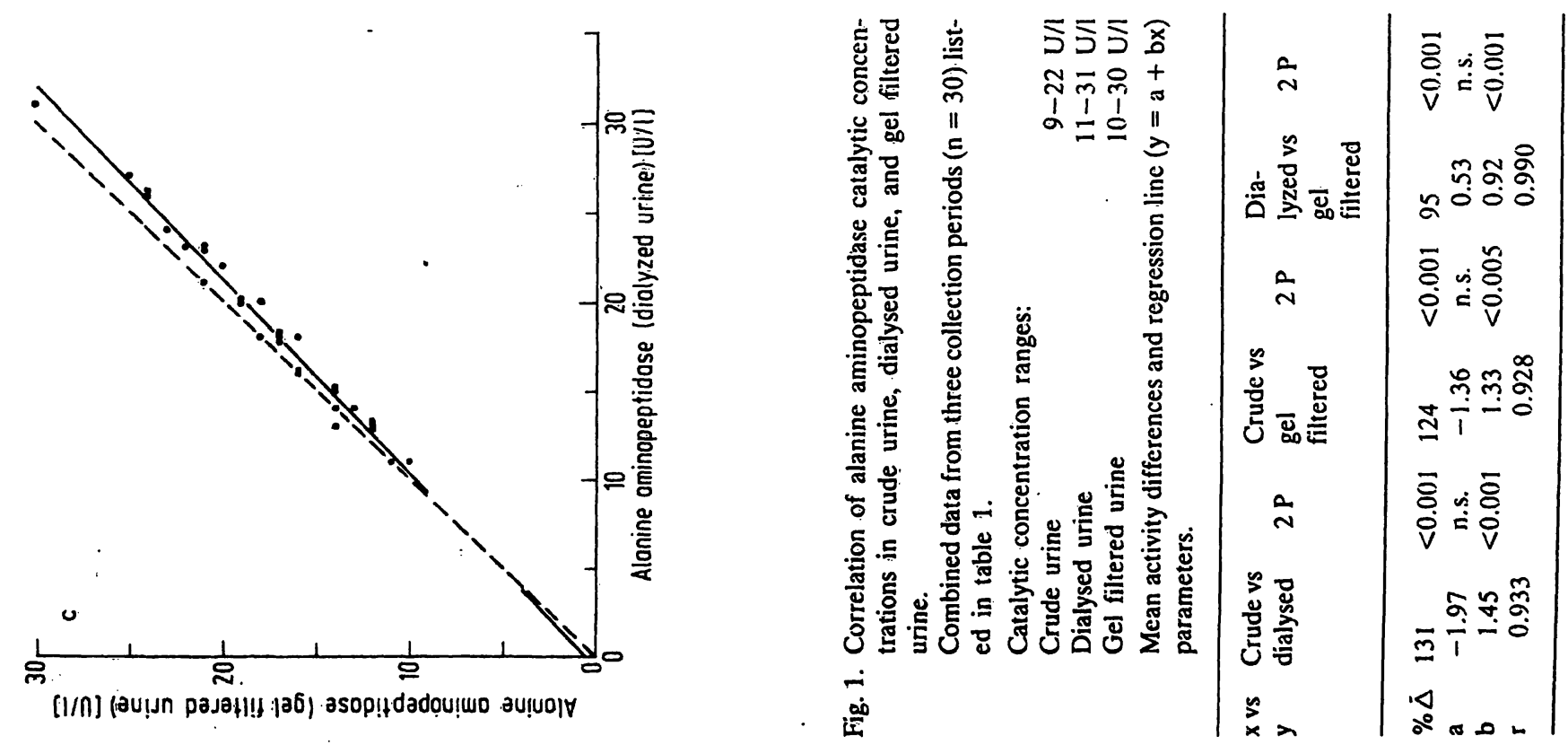
inhibition. Fluorimetric methods, however, are susceptible to other interferences and, in our opinion, less suited for the routine laboratory.

Occurrence of enzyme activators in urine is inferred by the observation that activity loss occurs in some urines during dialysis or gel filtration. On the other hand enzyme denaturation by sample preparation cannot be excluded with certainty. In this study, we found an activity loss of $\mathrm{N}$-acetyl- $\beta$ - $D$-glucosaminidase in 3 out of 30 dialysed samples (fig. 2a) but only an activity gain in gel filtered samples. Substantial activity loss of $\beta$-glucuronidase occurred in all but two dialysed samples. We believe that the enzyme was denatured by dialysis against water, because activity loss was avoided and activity gained by parallel dialysis against $150 \mathrm{mmol} / \mathrm{l} \mathrm{NaCl}$. In 6 out of 30 gel filtered samples, $\beta$-glucuronidase catalytic activity was also lower than in crude urine (fig. 3b). Decreases in activity occurred in 5 samples on day 2 and in 1 sample on day 3 . We interpret this as removal of an activator rather than enzyme denaturation. Decreases in activity in treated samples were not found for alanine aminopeptidase.

\section{References}

1. Raab, W. P. (1972) Clin. Chem. 18, 5-25.

2. Burchardt, U., Peters, J. E., Neef, L., Thulin, H., Grundig, C. A. \& Haschen, R. (1977) Z. Med. Labor.-Diagn. 18, 190212.

3. Price, R. G. (1982) Toxicology 23, 99-134.

4. Mondorf, W., Breier, J., Hendus, J., Scherberich, J. E., Machenrodt. G., Shah, P. M., Stille, W. \& Schoeppe, W. (1978) Europ. J. Clin. Pharmacol. 13, 133-142.

5. Szasz, G. (1967) Clin. Chim. Acta 15, 275-282.

6. Maruhn, D. (1976) Clin. Chim. Acta 73, 453-461.

7. Knoll, E., Wisser, H. \& Rautenstrauch, H. (1980) J. Clin. Chem. Clin. Biochem. 18, 53-58.

Grötsch, H. \& Mattenheimer, H. (1983) In: Methods of Enzymatic Analysis (Bergmeyer, H. U., ed.). 4th edition, Vol. 3, in press. Verlag Chemie, Weinheim.

8. Mattenheimer, H. (1968) in Praktische Enzymology (Schmidt, F. W., ed). pp. 355-385, Huber, Bern, Stuttgart.

\section{Recommendation}

As a result of this investigation we recommend that rat urine be prepared by gel filtration for the analysis of alanine aminopeptidase, $\beta$-glucuronidase and $\mathrm{N}$ acetyl- $\beta$ - $D$-glucosaminidase, in order to remove inhibitors and possible activators. Therslightly inferior effect of gel filtration upon alanine aminopeptidase, as compared to dialysis, should be disregarded for the sake of practicality. Gel filtration is fast and reproducible, several columns can be operated at the same time, and columns can be regenerated and used for several months.

Standardization of techniques is essential, especially when enzyme measurements in urine are used for the assessment of possible nephrotoxicity of drugs.

\section{Acknowledgement}

We thank Ms. E. Dichtl and Ms. R. Heun for their skillful assistance.
9. Maruhn, D. (1979) in Diagnostic Significance of Enzymes and Proteins in Urine (Dubach, U. C. \& Schmidt, U., eds.), pp. 22-29, Huber, Bern, Stuttgart, Vienna.

10. Kushinsky, S. \& Chen, V. L. (1967) Enzymol. Biol. Clin. 8, 266-282.

11. Grötsch, H., Berscheid, G., Grigolèit, H. G., Dagrosa, E. E. \& Hundt, H. K. L. (1981) Pharmacology 9, 422.

12. Peters, J., Schneider, I. \& Haschen, R. (1972) Cling. Chim. Acta 36, 289-301.

13. Werner, M., Maruhn, D. \& Atoba, M. (1969) J. Chromatog. 40, 254-263.

14. Szasz, G. (1970) Z. Klin. Chem. Klin. Biochem. 8, 1-8.

15. Price, R. G. (1979) In: Diagnostic Significance of Enzymes and Proteins in Urine (Dubach, U. C. \& Schmidt, U., eds.). pp. 150-160, Huber, Bern, Stuttgart, Vienna.

16. Gibey, R., Dupond, J.-L., Alber, D., Leconte des Floris, R. \& Henry, J.-C. (1981) Clin. Chim. Acta 116, 25-34.

\author{
Dr. Horst Götsch \\ Hoechst AG \\ Pharmaforschung Biochemie \\ Postfach 800320 \\ D-6230 Frankfurt/M 80 \\ and \\ Dr. Hermann Mattenheimer \\ Professor of Biochemistry \\ Presbyterian-St. Luke's Medical Center \\ 1753 W. Congress Parkway \\ Chicago, Ill. 60612 \\ U.S.A.
}

